\title{
A cell-type-specific dynamic Bayesian network model for spontaneous and optogenetically evoked activity in the primary visual cortex
}

\author{
Ali Mohebi ${ }^{1}$, Jessica A Cardin ${ }^{3}$, Karim G Oweiss ${ }^{1,2^{*}}$ \\ From Twentieth Annual Computational Neuroscience Meeting: CNS*2011 \\ Stockholm, Sweden. 23-28 July 2011
}

Reciprocal interaction between excitatory and inhibitory neurons within and between layers of the cerebral cortex is a major element of brain function. Ensemble extracellular recording techniques using mircroelectrode arrays have permitted recording spiking activity of many neurons simultaneously to characterize network function [1]. Identifying the type of neurons in these recordings is not straightforward due to the variability in extracellular spike shapes, and the irregularities often observed in their interspike interval characteristics. In this study, we used optogenetic tools to genetically target fast spiking interneurons in the primary visual cortex of mice [2]. We modulated their spiking activity by illuminating the region with very short pulses $(<1 \mathrm{~ms})$ of light $(\sim 470$ $\mathrm{nm}$ wavelength)in mice primary visual cortex. Using Dynamic Bayesian Network analysis [3], we assessed the effective connectivity between the recorded neurons in the presence and absence of light stimuli under distinct cortical states observed under light anesthesia. DBNs could identify the effective connectivity between putative excitatory pyramidal cells and inhibitory interneurons. These findings suggest a novel and unprecedented way to identify cortical neuronal circuits and characterize the dynamics of their computations in vivo.

\section{Author details}

'Department of Electrical and Computer Engineering, Michigan State University, East Lansing, MI 48824, USA. ${ }^{2}$ Neuroscience Program, Michigan State University, East Lansing, Ml 48824, USA. ${ }^{3}$ Department of Neurobiology, Yale University School of Medicine, New Haven, CT 06510, USA.

Published: 18 July 2011

\footnotetext{
* Correspondence: koweiss@msu.edu

'Department of Electrical and Computer Engineering, Michigan State

University, East Lansing, Ml 48824, USA

Full list of author information is available at the end of the article
}

\section{References}

1. Haider B, Duque A, Hasenstaub AR, McCormick DA: Neocortical Network Activity In Vivo Is Generated through a Dynamic Balance of Excitation and Inhibition. Journal of Neuroscience 2006, 26:4535-4545.

2. Cardin JA, Carlen M, Meletis K, Knoblich U, Zhang F, Deisseroth K, Tsai L, et al: Targeted optogenetic stimulation and recording of neurons in vivo using cell-type-specific expression of Channelrhodopsin-2. Nature Protocols 2010, 5:247-254

3. Eldawlatly S, Zhou Y, Jin R, Oweiss KG: On the Use of Dynamic Bayesian Networks in Reconstructing Functional Neuronal Networks from Spike Train Ensembles. Neural Computation 2010, 22:158-189.

doi:10.1186/1471-2202-12-S1-05

Cite this article as: Mohebi et al: A cell-type-specific dynamic Bayesian network model for spontaneous and optogenetically evoked activity in the primary visual cortex. BMC Neuroscience 2011 12(Suppl 1):05.

Submit your next manuscript to BioMed Central and take full advantage of:

- Convenient online submission

- Thorough peer review

- No space constraints or color figure charges

- Immediate publication on acceptance

- Inclusion in PubMed, CAS, Scopus and Google Scholar

- Research which is freely available for redistribution

Submit your manuscript at www.biomedcentral.com/submit
() Biomed Central 